EASTERN EUROPEAN JOURNAL OF TRANSNATIONAL RELATIONS

2019 Vol. 3 No. 1

DOI: $10.15290 /$ eejtr.2019.03.01.01

Adrian Niewęgłowski ${ }^{1}$

The Maria Curie-Skłodowska University, Poland

\title{
Current Problems Being Faced by the Consortia with Respect to Industrial Property in the Light of Empirical Research ${ }^{2}$
}

\begin{abstract}
This article presents the outcomes of empirical research conducted by the author, which included the science consortia currently operating in Poland. This term should be understood as referring to multi-lateral agreements concluded between academic units (universities), and sometimes also involves private businesses (interested in investing in new technologies). Following the proliferation of science consortia, which was particularly pronounced in 2010, many of these entities are currently facing major difficulties in their daily operations. These have resulted, inter alia, from the expanding membership structure, which can give rise to conflicts between consortium members, or from financial and organizational difficulties which can lead to some consortium members' being declaring bankruptcy. In addition, consortium agreements frequently fail to devise effective solutions to deal with such difficulties once they arise.
\end{abstract}

Keywords: Consortium, civil-law partnership agreement, industrial property rights, research, bankruptcy, licenses, universities

\section{Introduction}

Cooperation in the field of research is a frequently discussed issue in many countries. In Poland, the so-called Package of Legal Acts to Reform Polish

$1 \mathrm{PhD}$, Assistant Professor, Lecturer at the Faculty of Law and Administration, The Maria CurieSkłodowska University in Lublin (Poland). ORCID: https://orcid.org/0000-0002-0948-9813. E-mail: adrian.nieweglowski@ poczta.umcs.lublin.pl.

2 This article constitutes a modified version of the paper presented by the author on 8 March 2019 at the first National Scientific Conference for Doctoral Students entitled "Industrial Property Rights in the $21^{\text {st }}$ Century - Theory and Practice." 
Science $(2010)^{3}$ gave an impetus to the proliferation of multilateral agreements on research commercialization. This was when a set of legal regulations came into force to facilitate the concluding of consortium agreements by universities. However, in contrast to some other EU Member States, they concerned a limited number of issues. All they essentially did was stress the importance of consortia in developing a knowledge-based economy in Poland. Along with the growing number of science consortia in Poland, the regulations applied to these bodies began to decline in number. Obviously, as one could expect in similar cases, practical problems did not vanish. On the contrary, they began to intensify over time, as the consortium members, in establishing these bodies, had hardly foreseen what the future was about to bring. Now, towards the end of the second decade of the twentieth-first century, numerous consortia have been set up in Poland, which have many members and hardly any means to solve their problems via mutual cooperation.

The purpose of this article is to analyse the problems encountered by consortia within the limits imposed by the length and format of a scientific paper.

The article presents the outcomes of empirical research (including diagnostic surveys) conducted by the author in the course of his cooperation with the Centre for Knowledge and Technology Transfer at the Maria Curie-Skłodowska University in Lublin, ${ }^{4}$ between 2012 and 2018. The research covered ten science consortia operating in Poland, as well as four consortia established abroad (in Germany and Austria). In 2012-2018, the author not only familiarized himself with the operational conditions specific to these consortia, but also scrutinized some of the agreements they had entered into. These included agreements for the transfer of industrial property rights (especially those pertaining to patents), licensing agreements, joint property rights agreements, etc. ${ }^{5}$ Moreover, during that period, the author developed his own conclusions, and the information he had gathered with the data available in the literature on the subject matter, regarding

3 This refers to a set of legal Acts drawn up and adopted (in Poland) in the first decade of the twenty-first century, which were expected to facilitate, inter alia, cooperation in the fields of science and business. The Package of Legal Acts to Reform Polish Science included the Act on research institutes, the Act on financing science, and the amended Act on the Polish Academy of Sciences. However, at the time of writing this article, many of the specific provisions included in these acts only have a historic meaning, and it is thus sufficient to outline this matter in brief. The Package of Acts to Reform the Polish Science was published in the Journal of Laws of the Republic of Poland of 2010, No. 96 of 4 June 2010, under items 615 to 620.

4 The author is currently a member of the Supervisory Board of the Centre for Knowledge and Technology Transfer at Maria Curie-Skłodowska University in Lublin.

5 In total, in 2012-2018, the author analysed around 350 agreements which the consortia had concluded with private businesses. 
research commercialization (see, in particular, Salamonowicz 20186; SieńczyłoChlabicz, 2017).

\section{Types of Consortia in the Field of Industrial Property}

Based on these analyses, several types of consortia in the field of industrial property can be distinguished. ${ }^{7}$

The first group comprises closed consortia, which affiliate entities operating within one sector of economy (which implies that their members can include either universities or entrepreneurs interested in investing in new technologies). The characteristic feature of these bodies is that their operations are based exclusively on civil-law contracts, i.e. their members do not form separate legal entities such as commercial-law companies.

The second group is made up of open consortia, which comprise both academic units of different types (universities, technical universities, etc.) and businesses. Their operational model envisages a continuous inclusion of new members, and they constitute an optimal solution in a knowledge-based economy (providing examples of establishing a relationship between science and industry). Over time, as their development continues, they transform into commercial-law companies. ${ }^{8}$

The third type is referred to as patent-holding consortia (Sikorski, 2013; Blakeney, 2009). These bodies do not conduct production activities or render services by exercising the rights which they hold (patents, rights in registration, etc.). They license these rights to businesses which then exercise them and undertake production on their basis. The underlying objective of patent-holding consortia is to collect fees for granting licenses to businesses for the use of inventions and designs. ${ }^{9}$

The fourth group constitutes production consortia which conduct production activities or render services, by utilizing certain protected solutions (patented

6 The book by M. Salamonowicz (2018) presents (in the form of appendices) the results of diagnostic surveys that were conducted by that author. They were also taken into consideration while preparing this article for printing.

7 The presented division of consortia is of a typological character. It is, therefore, based on those characteristics that prevail within the internal structure of a given consortium. The individual types of consortia were distinguished on the basis of observations of the legal transaction practices in Poland and in other European Union countries.

8 While such consortia are viewed as an optimal form of cooperation in the field of industrial property, they are not as popular in Poland as, for instance, in Austria or Germany.

9 As in other similar cases, the consortia in question can instigate a range of negative phenomena, such as the abuse of industrial property rights. In extreme cases, they might even be referred to as "patent trolls." See, in particular, Ann Ch. (2009). "Patent Trolls - Menace or Myth". In: W. Prinz zu Waldeck und Pyrmont, M. J. Adelman, R. Brauneis, J. Drexl \& R. Nack (Eds.), Patents and Technological Progress in a Globalized World: Liber Amicorum Joseph Straus (pp. 355-364). Berlin-Heidelberg: Springer-Verlag. 
inventions, etc.), by virtue of their own research or technical workers. They operate as commercial-law companies, usually as capital companies (e.g. limited-liability companies).

There are also consortia of a mixed nature. For instance, production consortia often have an open character. This is due to the fact that they require recapitalization at a certain stage of their development, which gives rise to inviting new members to join the consortium. By contrast, patent-holding consortia frequently operate as closed consortia.

There is a lack of work on scientific consortia in Polish academic literature. In general, the authors focus their attention on other consortia - for example, they analyse construction consortia or public procurement consortia. ${ }^{10}$ The authors pay most attention to the legal nature of consortia. In this respect, two views have been noted in particular in the literature. According to one of them, represented, among others, by Włodyka: "The consortium agreement is an extended civil law partnership agreement (or possibly a general partnership)"11. On this basis, two types of consortia can be distinguished: consortia in the form of commercial companies and 'internal' shareholder agreements. ${ }^{12}$ In another view, the consortium agreement is an unnamed agreement ${ }^{13}$, but this statement does not in fact explain the legal nature of the consortium agreement. When referring these scientific views to consortia in the

10 The following types of consortia are listed in the basic studies: banking, construction, insurance, securities, forfaiting. See Opalski, A. (2018). Umowa konsorcjum. In: W. J. Katner (Ed.), System prawa prywatnego: umowy nienazwane (pp. 1189-1191), vol. 9. Warszawa: C. H. Beck. The last quoted author does not give, as an example of a consortium, a consortium in the field of industrial property. In another study, M. Spyra and S. Włodyka mention only "scientific consortia" as a kind of consortium in general. However, they do not discuss them in more detail. See Spyra, M. \& Włodyka, S. (2017). Konsorcjum. In: M. Stec (Ed.), System prawa handlowego. Prawo umów handlowych (p. 869), vol. 5. Warszawa: C. H. Beck. The existence of scientific and industrial consortia in Poland is recognised by K. Muchowska-Zwara although in her book she devotes one page to them. See Muchowska-Zwara, K. (2015). Prawne problemy funkcjonowania konsorcjów uczestniczqcych $w$ obrocie regulowanym przez Prawo zamówień publicznych. Warszawa: C. H. Beck. However, that author's omission of scientific consortia is justified by the narrow thematic scope of her book. More on the types of consortia: Stecki, L. (1997). Konsorcjum (p. 57). Toruń. Publisher "Organizer's House". The lack of scientific work on consortia in the field of industrial property in the Polish literature means that it is necessary to rely on empirical research. At the same time, the use of foreign legal literature must be made with caution. The regulations concerning consortia in the European Union member states differ (there is no harmonisation in this respect). Therefore, it is difficult to formulate conclusions for the Polish legal system on this basis.

11 Włodyka, S. (2000). Strategiczne umowy przedsiębiorców (p. 259). Warszawa: C. H. Beck. L. Stecki is of the same opinion (Stecki, 1997, p. 140).

12 Szyszko, R. (2019), p. 67-71.

13 Strzępka, J. A. (2018). Umowy o generalne wykonawstwo. In: J. Rajski (Ed.), System prawa prywatnego: prawo zobowiazań - część szczegótowa (pp. 599-600), vol. 7. Warszawa: C. H. Beck. 
field of industrial property, the following must be said: industrial property consortia have their own specificities. They cannot be considered as banking, insurance or construction consortia. The current Polish literature on consortia law cannot explain the essence of scientific consortia or solve problems related to their functioning. Therefore, further analysis should be based on the results of empirical research.

\section{The Main Problems Concerning the Functioning of Consortia}

In the course of the research, it was found that the consortia operating in the sphere of industrial property faced a range of similar problems. These mainly involve Polish consortia which have not evolved into commercial-law companies and continue to operate exclusively on the basis of agreements whose provisions resemble those of civil-law partnership agreements. These issues can be basically presented as follows:

All decisions regarding the use of industrial-property rights are made by all consortium members. As the number of members increases (in the case of open consortia), it becomes harder to reach a consensus, even on the most fundamental issues connected with the ongoing use of patents or other industrial property rights. Such problems are avoided by those consortia which have appointed members responsible for the management of rights, while also determining that any strategic matters (such as disposing of or pledging the rights) require a decision to be made by all members. Based on the conducted research and observations, the conclusion can be drawn that in cases in which there are more than fifteen consortium members (universities and/or businesses), the consortium agreement should regulate the obligatory conversion of the consortium into a capital company (with the decisionmaking process being distributed among the management board and another body, e.g. a meeting of shareholders). ${ }^{14}$ An alternative solution can consist of including express provisions in the consortium's agreement to lay down the rules for making decisions by a majority of votes, and to authorize one or several members to manage, on an ongoing basis, the rights controlled by other members.

There are no provisions for terminating the cooperation. If the emphasis of the consortium agreement is on issues related to the ongoing cooperation between the parties, they can encounter a problem once it proves necessary to dissolve the consortium. The lack of agreement between the consortium members triggers the need to cash in the property rights constituting their joint property.

14 The so-called automatic transformation clause constitutes a solution which has already proven effective in the consortium practice. It involves including in the consortium agreement a provision under which, on attaining a specific level of revenues in two consecutive settlement periods (e.g. over EUR 800,000 in two consecutive financial years); the consortium is transformed into a more advanced legal entity (e.g. from a civil-law partnership into a commercial-law company). 
There is no strategy in place to be implemented if one of the consortium members declares bankruptcy. ${ }^{15}$ Practically speaking, bankruptcy is an event which stigmatizes not only the business entity going bankrupt but also the entities cooperating with it, including consortium members. A prolonging state of bankruptcy can have a negative impact on the image of the entire consortium and its operations. From a long-term perspective, it can lead to a reduction in the value of their property rights. Therefore, it is of utmost importance, from the point of view of the general interests of the consortium members, to determine the operational mode in the event of one of them declaring bankruptcy.

There is no licensing policy (i.e. no uniform conditions have been established, which must be satisfied by every potential licensee). Unless the consortium is driven by uniform and premeditated licensing standards, the choice of contractors is often accidental. As a result, the cooperation between the consortium and its licensees might not smoothly progress. Problems related to the timely collection of invention or design realization fees are also likely to appear over time.

The consortium agreement includes no adaptation ${ }^{16}$ or arbitration clauses.

Each of these is a source of major functional problems for consortia operating in the domain of industrial property. Although it would be undoubtedly difficult to identify a situation creating the most serious complications, it is more than certain that any changes to the consortium composition which have not been foreseen by the parties on concluding multi-annual agreements can bring about major consequences. At the same time, one might be right to note that such changes hardly appear unusual, and are unavoidable whenever the cooperation with a given contractor is planned to last a long time. As many consortia are attracted by the idea of pursuing long-standing cooperation, their members should envisage the possibility that composition changes can occur, for various reasons (a member leaving the consortium, a consortium partner being dissolved, etc.).

15 Bankruptcy may concern those of the industrial property consortium members that are not state-owned universities. As is commonly known, a state-owned university cannot be declare bankruptcy. See Article 6 of the Act of 28 February 2003 - Bankruptcy Law (uniform text: Journal of Laws of 2019, item 498 as amended). Hereinafter: the Bankruptcy Law. See Kruczalak-Jankowska, J. (2016). Podmiotowy zakres prawa upadłościowego (zdolność upadłościowa). In: A. Hrycaj, A. Jakubecki \& A. Witosz (Eds.), System prawa handlowego: prawo restrukturyzacyjne i upadtościowe (pp. 655-657), vol. 6. Warszawa: C. H. Beck.

16 The term "adaptation clauses" is understood by the author as the contractual provisions aimed at adjusting the contract to the actual state of affairs (e.g. increased prices or reduced demand for certain technical solutions). Such circumstances can affect various transaction parties, with science consortia constituting no exception (Strugała, 2013). 


\section{Specific Problems Concerning the Functioning of Consortia}

Negligence in updating entries in the registers kept by both Polish and foreign patent offices is a frequent irregularity, related to personal changes introduced in the course of the consortium's functioning. This issue has major practical implications. Industrial property rights belong to a group of subjective rights which require entries to be made in registers of various types (patent register, utility model register, etc.). ${ }^{17}$ When it comes to the transfer of such rights (through sales, donation, etc.), a change to the authorized party must be recorded in the register. Otherwise, it is the transferor (i.e. the party that which had been entered in the appropriate register as the authorized person before the right was transferred) which will be viewed by third parties as the authorized holder of a given patent or protected right. An entity which has not been entered in the register (e.g. the transferee) need not be treated as the authorized holder by any third parties. ${ }^{18}$ This principle is binding in most European countries, including Poland. ${ }^{19}$ Similar rules have also been adopted with respect to industrial property rights and are binding throughout the European Union..$^{20}$

Consortia usually operate on the basis of a legal relationship taking the form of a civil-law partnership. Contrary, for instance, to a joint-stock company, this partnership has no legal capacity other than that of its partners. Therefore, it is not the civil-law partnership which is entered as the authorized holder of industrial property rights but its individual partners, i.e. all consortium members. Practically speaking, the problem arising from the co-occurrence of the following elements of the actual state of affairs are becoming increasingly frequent:

17 This is what makes this group of subjective rights different, in particular from copyright. The whole world, in line with the Berne Convention for the Protection of Literary and Artistic Works (9 September 1886), abides by the principle that copyright protection applies even in the absence of any formalities. Therefore, there is no need for copyright to be entered in any register which would entail the establishing or termination of its legal protection.

18 The practical implication of an entry in the register is reflected on attempting at proving one's right of action in the proceedings regarding an infringement of industrial property rights, as the lack of such an entry makes it difficult to effectively pursue one's claim (and to prove the right vested in the claimant).

19 See Article 67 (3) of the Act of 30 June 2000 - Industrial Property Law (uniform text, Journal of Laws of 2017, item 776).

20 The right to use an EU trade mark can be seen as an example. It is granted by the European Union Intellectual Property Office (EUIPO), with its seat in Alicante. Under a EUIPO decision, the party concerned may enjoy territorially broad protection which is not limited to any specific EU Member State. Pursuant to Article 17 (6) of the Council Regulation (EC) of 26 February 2009 on the Community Trade Mark (OJ L 78/1, 24.3.2009): “As long as the transfer has not been entered in the Register, the successor in title may not invoke the rights arising from the registration of the Community trade mark." The obligation to disclose change to the authorized entity in the appropriate register serves the purpose of strengthening the security of legal transactions. See more in McGuire, M-R. (2015). Commentary on Article 17. In: G.H. Hasselblatt (Ed.). Community Trade Mark Regulation. A Commentary (p. 469). München-Oxford: Beck-Hart-Nomos. 
The consortium is initially formed by several or more than ten partners which enter into a civil-law agreement. The partners (consortium members) are listed in the registers kept by patent offices (or the EUIPO) as the authorized holders of the industrial property rights exercised jointly by the consortium ${ }^{21}$;

As the consortium develops, its composition changes, with some members deciding to leave its organization (e.g. by terminating their participation in the civillaw partnership). They are, nevertheless, still listed in the registers as the authorized holders of industrial property rights;

When the former partners are replaced by new consortium members, no changes are made to the register (i.e. it still includes entries on the former partners);

At a later date (usually when the risk of a court dispute regarding an infringement of industrial property rights becomes apparent), the partners become aware of the need to make changes to the register regarding the authorized holders of industrial property rights. However, Patent Offices refuse to effect such changes without the consent of those partners who have left the consortium. ${ }^{22}$

The factual circumstances which formed the subject matter of the decision passed by the Provincial Administrative Court in Warsaw on 9 December 2011 might be seen as proving the complexity of the situation discussed above. ${ }^{23}$ In practical terms, the fact that Polish courts require consent to be given by the former consortium members prior to listing the new partners as the authorized holders of industrial property rights poses a serious obstacle to conducting further activities. In general, having left the consortium, the former partners are no longer interested in engaging in its affairs. Furthermore, at this point, they may no longer exist in the legal sense (e.g. having been removed from the register due to the conclusion of bankruptcy or liquidation proceedings). Therefore, it might not only prove difficult, but even impossible, to obtain their consent to amending entries in the registers kept by Patent Offices/the EUIPO.

Needless to say, such situations arise through the fault of the persons managing the consortium and could be avoided by making ongoing updates to the registers kept by Patent Offices. Nonetheless, the problem exists and needs to be dealt with. This issue remains problematic, not only when the assumption is made that the consortium

21 The consortium members are jointly listed in the register as the authorized holders, e.g., of a patent or other protected right.

22 Patent Offices sometimes require the presentation of the transfer agreement, or any other agreement, proving the former consortium member's consent to listing a new person as the authorized holder of the patent or industrial design right.

23 Case No. VI SA/Wa 2033/11. The wording of the court decision (in Polish) is available on http://www.orzeczenia-nsa.pl/wyrok/vi-sa-wa-2033-11,znaki_towarowe_wlasnosc_ przemyslowa,29884cf.html (accessed on April 6, 2019). 
would still operate within its previous structure, but it should also be addressed when there is a need to transform the consortium, for instance, into a capital company. ${ }^{24}$

The following solution could be proposed to deal with the problem in question.

Industrial property consortia are established to serve a specific purpose, which is the commercialization of patents or other intellectual property rights, as the case may be, and all the parties joining the consortium must be aware of that. In order to enable the effective commercialization of an industrial property, certain legal and substantive actions are required, including the authorized parties' being entered in the appropriate registers, such as those kept by the national Patent Offices and the EUIPO. Otherwise, the purpose for which a consortium has been established might not be achieved, as its members might face difficulties in prosecuting cases of infringements of intellectual property rights, and in finding persons interested in obtaining the licenses to use inventions or other intangible assets.

In view of the consortium's purpose, it should be assumed that, until that purpose is achieved, the industrial property rights remain with the current, not the former, members of the consortium operating as a civil-law partnership. These rights should be viewed as constituting joint property which can only be divided if the partnership (consortium) is dissolved. In other words, as long as the property exists, it cannot be divided ${ }^{25}$ and is used to achieve the partnership's purpose, which, in the case in point, involves the commercialization of industrial property. Obviously, in such a scenario, the interests of those partners who have left the consortium are also protected, as they may submit a claim to the remaining consortium members to perform the appropriate settlements (e.g. pecuniary). As is properly noted, on leaving a civil-law partnership (i.e. the consortium's form at the initial operational stage), the partner does not have the right to its joint property but may merely claim that a settlement (whether pecuniary or non-pecuniary) is made and compensation provided (Herbet, 2008, p. 429; see also Lic, 2013). ${ }^{26}$

Adopting the above assumptions makes it possible to eliminate the problem of amending entries in the register kept by the Patent Office/EUIPO. Assuming that industrial property rights continue to form the consortium's assets, it should

24 One of the consortia included in the research which had encountered such a problem had been transformed into a commercial-law company. However, the Patent Office refused to enter the transformed company in the register, claiming that the former partners had also to give their consent.

25 Such solutions have been envisaged in the legal Acts of various EU Member States. See, for instance, Article 863 of the Act of 23 April 1964 - Polish Civil Code (uniform text: Journal of Laws of 2018, item 1025), hereinafter: the Civil Code. A similar provision is stipulated in Par. 719 (1) of the German Civil Code (BGB), Federal Law Gazette (Bundesgesetzblatt): [I] p. 42, $2909 ; 2003[\mathrm{I}]$ p. 738 as amended.

26 If the consortium is transformed (e.g. into a capital company), the obligation to make the appropriate settlements passes to the company arising from such transformation. 
also be noted that their holders are at any time the current, rather than the former, partners (the latter being given the right to claim a settlement, whether pecuniary or otherwise). Entries regarding industrial property rights may, therefore, be updated on the basis of a uniform text of the consortium agreement (by removing the former partners and entering the new ones).

Notwithstanding the foregoing, in view of the emerging practical doubts, the inclusion of the following provision into consortium agreements should be postulated: "The Parties agree that, in the event of leaving the consortium, the partner grants consent to amending the entries in the appropriate registers regarding the industrial property rights constituting the joint property of the consortium. The consent referred to in the preceding sentence shall involve in particular removing the resigning partner from, and entering a new partner in, the register, in accordance with the uniform text of the consortium agreement."

\section{The Impact of Bankruptcy on a Consortium}

The impact of bankruptcy on a consortium is another problem worth attention. It should be assessed from two different angles, i.e. from the consortium member's perspective, and from the viewpoint of an affiliated entity (e.g. a person to whom the consortium has granted a license).

As previously mentioned, the problem of a consortium member's declaring bankruptcy tends to be marginalized in Polish legal-transaction practice. ${ }^{27}$ Only two of the Polish consortia included in the research envisaged certain solutions to be implemented should any of their members go bankrupt. These were limited to a simple statement "in the event of a consortium party declares bankruptcy, the consortium shall be dissolved." It seems that the parties, when seeking to establish permanent cooperation, should rather attempt to introduce certain instruments to assist one or several consortium members to overcome their economic crisis. These might include a temporary exemption of the partner threatened with insolvency from the periodic fee imposed for the protection of industrial property rights. Another solution might be to grant a loan or increase that partner's profit participation. Many consortium members do not seem bothered by one of the partners declaring bankrupt, or facing the risk of bankruptcy, nor are they interested in introducing any specific provisions to the consortium's agreement to grant assistance to such a partner.

However, it should be remembered that the consortia operating in the field of industrial property have their specific features, and their existence is based on intangible property rights. In the event of a declared bankruptcy with respect to a consortium member, its place will be taken by a trustee in bankruptcy seeking

27 Of note is the fact that the consortia operating in Austria and Germany which were included in the research had taken the bankruptcy issue into consideration. 
the fullest satisfaction for creditors, and one of the sources in this respect will be the revenue generated from the industrial property rights held by the consortium. The trustee's standpoint will also have to be taken into consideration in managing the joint industrial property rights. Therefore, the partner going bankrupt should not be treated as an isolated legal event solely affecting that partner. Depending on the legal form of the consortium, its consequences can differ, including the consortium's agreement termination, which is likely to compromise the purpose originally set by the parties.

The impact of bankruptcy on licensing agreements is not usually an issue which is included in the consortium's agreement. However, based on this research, it appears that both Polish and foreign consortia seek to include satisfactory provisions on this matter in the licensing agreements which are directly concluded with contractors. Naturally, these provisions usually refer to the licensee declaring bankruptcy, stipulating that, on the occurrence of this legal event, the licensing agreement is deemed expired. ${ }^{28}$ The introduction of such contractual clauses appears hardly surprising, as the licensee declaring bankruptcy implies that its financial situation is poor, and the likelihood of the consortium's receiving compensation (i.e. the license fee), for granting access to an intangible asset, becomes smaller. Of note is also the fact that in most countries bankruptcy is viewed as a circumstance stigmatizing the business entity and possibly also its contractors. Therefore, a prompt dissolution of the legal relationship with such a licensee is often treated by the licensor not only as beneficial but also as desirable.

The leeway for introducing specific provisions to enable the immediate dissolution of the legal relationship in the event of the licensee's being declared bankrupt is not usually unlimited. In Poland, such contractual clauses are seen as violating Article 83 of the Bankruptcy Law, which reads "Any contractual provisions which in the case of filing a bankruptcy petition or declaring a bankruptcy, provide for a change to, or dissolution of, the legal relationship in which the bankrupt is party shall be invalid." Consortium members are often unaware of the interdiction resulting from Article 83 of the Bankruptcy Law and tend to include clauses in their licensing agreements which, in essence, violate this provision. The Polish legislation has assumed that the contracting parties may not freely decide on terminating the agreement if one of them declares bankruptcy. This state of affairs affects not only

28 Nonetheless, no similar provisions are envisaged with respect to one or several consortium members declaring bankruptcy. In this case, none of the parties to the licensing agreement has any interest in the early termination of their legal relationship. This is due to the fact that the continuing performance of the licensing agreement makes it possible for the licensor to collect license fees and, thus, to reduce its liabilities towards creditors, while the licensee seeks the return on the outlays which it has incurred on entering the licensing agreement, for which the ability to exercise the rights provided thereunder appears indispensable. 
the contracting parties themselves, but also the bankrupt's creditors whose claims should be satisfied.

The consortium members' lack of awareness of the interdiction on introducing the clauses referred to above might stem from the fact that different solutions are adopted by individual countries. In some countries, the clauses which provide for agreement termination due to bankruptcy are not automatically invalid, as sometimes their validity is determined by a body conducting bankruptcy proceedings (e.g. a bankruptcy judge). As has been reported in the literature, inter alia, Argentine law stipulates that whenever there is a provision determining that a licensing agreement has expired due to one party's declaring bankruptcy or filing a bankruptcy petition; the bankruptcy judge retains the leeway to decide whether such an agreement should indeed expire. The judge may, therefore, hold the agreement valid by finding the provisions on agreement termination due to bankruptcy to be contradictory to public order (see Liberstein, Feingold, James \& Rosenblatt, 2012). The reference solution seems better than the one envisaged by the Polish legislation, as in some cases the license's expiry will not adversely impact the bankruptcy proceedings. It thus seems more beneficial to grant a certain amount of leeway to the judge, or another body than to determine the matter in advance. This approach appears better adjusted to market needs.

\section{Conclusions}

Undoubtedly, the conclusions and opinions presented above do not exhaust the complex problem of industrial property in consortia. Actually, only a few issues which have raised practical doubts in the light of the author's empirical research have been outlined and might constitute the starting point for further analyses. To sum up, from the considerations presented in the article certain conclusions can be drawn. The current legislative status is rather deficient when it comes to the problem of industrial property in the context of consortia. However, it is worth noting that over the years these bodies have evolved into increasingly complex legal structures, which implies that certain practical problems should be anticipated by their members, and the effective provisions should be included in the founding agreements. Without the appropriate contractual determination of specific issues, the emerging problems are likely to be difficult to eliminate by referring to general provisions. 


\section{CURRENT PROBLEMS BEING FACED BY THE CONSORTIA WITH RESPECT...}

\section{REFERENCES}

Ann Ch. (2009). Patent Trolls - Menace or Myth. In W. Prinz zu Waldeck und Pyrmont, M. J. Adelman, R. Brauneis, J. Drexl \& R. Nack (Eds.), Patents and Technological Progress in a Globalized World: Liber Amicorum Joseph Straus (pp. 355-364). Berlin-Heidelberg: Springer-Verlag.

Blakeney, M. (2009). Biotechnological Patenting and Innovation. In W. Prinz zu Waldeck und Pyrmont, M. J. Adelman, R. Brauneis, J. Drexl \& R. Nack (Eds.), Patents and Technological Progress in a Globalized World: Liber Amicorum Joseph Straus (pp. 229-242). Berlin-Heidelberg: Springer-Verlag.

Herbet, A. (2008). Spótka cywilna. Konstrukcja prawna [Civil law partnership. Legal structure]. Warszawa: C. H. Beck.

Kruczalak-Jankowska, J. (2016). Podmiotowy zakres prawa upadłościowego (zdolność upadłościowa) [Persons Falling Within the Scope of Insolvency Law (Bankruptcy Capacity)]. In A. Hrycaj, A. Jakubecki \& A. Witosz (Eds.), System prawa handlowego: prawo restrukturyzacyjne i upadłościowe (pp. 655-657), vol. 6. Warszawa: C. H. Beck.

Liberstein, M., Feingold, S., James, C., \& Rosenblatt, P. (2012). "Recent developments and best practices in trademark licensing”. In G. J. Battersby \& C. W. Grimes (Eds.). Licensing update (pp. 30-31). New York: Wolters Kluwer Law \& Business.

Lic, J. (2013). Spótka cywilna. Problematyka podmiotowości prawnej [Civil Law Partnership. Issues of Legal Personality]. Warszawa: C. H. Beck.

McGuire, M-R. (2015). Commentary on Article 17. In G.H. Hasselblatt (Ed.). Community Trade Mark Regulation. A Commentary (p. 469). München-Oxford: Beck-Hart-Nomos.

Muchowska-Zwara, K. (2015). Prawne problemy funkcjonowania konsorcjów uczestniczacych $w$ obrocie regulowanym przez Prawo zamówien publicznych [Legal Problems of the Functioning of Consortia Participating in Trade Regulated by the Public Procurement Law]. Warszawa: C. H. Beck.

Opalski, A. (2018). Umowa konsorcjum [Consortium Agreement]. In W. J. Katner (Ed.), System prawa prywatnego: umowy nienazwane (pp. 1189-1191), vol. 9. Warszawa: C. H. Beck.

Salamonowicz, M. (2018). Treśś i charakter prawny umowy o prace badawczo-rozwojowe [The Concept and Legal Nature of a Research and Development Contract]. Warszawa: Wolters Kluwer Polska.

Sieńczyło-Chlabicz, J. (Ed.) (2017). Komercjalizacja i transfer wyników badań naukowych i prac rozwojowych z uczelni do gospodarki. Komentarz [Commercialisation and Transfer of Research and Development Results from Universities to Business. Commentary]. Warszawa: C. H. Beck.

Sikorski, R. (2013). Funkcjonowanie zasobów patentowych w prawie konkurencji Unii Europejskiej [The Functioning of Patent Pools in European Union Competition Law]. Warszawa: C. H. Beck.

Spyra, M. \& Włodyka, S. (2017). Konsorcjum [Consortium]. In M. Stec (Ed.), System prawa handlowego. Prawo umów handlowych (p. 869), vol. 5, Warszawa: C. H. Beck.

Stecki, L. (1997). Konsorcjum [Consortium]. Toruń. Publisher “Organizer's House”. 


\section{EASTERN EUROPEAN JOURNAL OF TRANSNATIONAL RELATIONS}

Strugała, R. (2013). Standardowe klauzule umowne adaptacyjne, salwatoryjne, merger, interpretacyjne oraz pactum de forma [Standard Contractual Clauses for Adaptation, Salvatoria, Merger, Interpretation and pactum de forma]. Warszawa: C. H. Beck.

Strzępka, J. A. (2018). Umowy o generalne wykonawstwo [General Construction Contracts]. In J. Rajski (Ed.), System prawa prywatnego: prawo zobowiqzań - część szczegótowa (pp. 599600), vol. 7. Warszawa: C. H. Beck.

Szyszko, R. (2019). Umowy wspólników, inwestycyjne, konsorcja, joint-venture i inne podtypy spótki cywilnej - środki ochrony prawnej w przypadku naruszenia przez uczestnika [Shareholders' Agreements, Investment Agreements, Consortia, Joint Ventures and Other Subtypes of Civil Partnership - Remedies in Case of a Violation by a Participant]. Warszawa: C. H. Beck.

Włodyka, S. (2000). Strategiczne umowy przedsiębiorców [Strategic Agreements of Entrepreneurs]. Warszawa: C. H. Beck. 